\author{
Case Study \\ www.ijrap.net (ISSN:2229-3566)
}

\title{
A CASE STUDY: ANUVASANA BASTI WITH KETAKYADI TAILAM IN LOW BACKACHE
}

Gopitha P. G. ${ }^{1 *}$, Joshi George ${ }^{2}$

${ }^{1}$ PG Scholar, Department of Panchakarma, MVR Ayurveda Medical College, Kannur, Kerala, India

${ }^{2}$ Guide and Associate Professor, Department of Panchakarma, MVR Ayurveda Medical College, Kannur, Kerala, India

Received on: 26/04/21 Accepted on: 05/06/21

\begin{abstract}
*Corresponding author
E-mail: gopitharenjith@gmail.com
\end{abstract}

DOI: 10.7897/2277-4343.120364

\begin{abstract}
Low back ache is the pain in the lumbo-sacral region triggered by combination of factors like muscle strain, overuse, injury or trauma to muscles, ligaments and disc that support the spine. A diagnosed case of Low back ache came with complaints of pain over low back region, stiffness and limitation in the movements of lumbo-sacral joint since 2 years. There was no history of trauma or fall and other systemic illness. A positive family history was noted. In Ayurveda, it can be correlated with Asthigata vata and deranged Vata dosha is the main cause for pain. The primordial treatment for Vata dushti is Basti, especially Anuvasana vasti. Ketakyadi taila is very effective in Asthigata vata. So Anuvasana Basti with Ketakyadi tailam is administered continuous 9 days. The clinical symptoms like low back pain and stiffness got relieved markedly on $5^{\text {th }}$ day itself. After the entire treatment the condition of the patient improved remarkably.
\end{abstract}

Keywords: Low back ache, Asthigata vata, Anuvasana Basti, Ketakyadi tailam

\section{INTRODUCTION}

In this era, due to continuous work in sitting and standing posture, the pressure over the spine got increased. The causes for Low back ache are nerve root compression, local causes, muscle sprain or strain etc ${ }^{1,2}$. The pain may be acute or chronic, mild to severe, sharp or shooting in nature and sometimes extend up to the ankle or foot ${ }^{3}$. It gets worsened by standing or walking or continuous sitting. Positive family history, trauma or fall, history of spinal surgery is prone conditions ${ }^{4}$. Keeping good posture while doing works can help one to reduce the severity of pain. In Ayurveda, Basti is the prime treatment for Asthigata vata. Charaka Acharya quoted that: even though we pour water in roots of a tree, it shows the effect in their fruits and flowers; likewise Anuvasana Basti administered through anal route has action on whole body ${ }^{5}$. In Vata vikara, Anuvasana Basti is indicated for 9 or 11 days. This is the first attempt of administration of Anuvasana Basti for continuous 9 days. Ketakyadi taila is indicated in Asthigata vata ${ }^{6}$.

\section{Case report}

A 40 year old male patient came to Panchakarma OPD of MVR Ayurveda Medical College, Parassinikadavu, Kannur, Kerala, with the complaints of low back pain and stiffness leading to limitation in the movements since 2 years. The patient experienced pain in the lumbo-sacral region at first. After 2 months he experienced stiffness and limitation in the movements too. He took pain killers and got temporary relief. The condition got aggravated during working hours. There was no history of trauma or fall. Sleep is disturbed due to pain. The patient is Carpenter by profession and his job versus the condition. The family history showed that his mother and elder brother have the same conditions.

\section{General examination}

Vitals of the patient - stable

Blood pressure - 120/82
Pulse rate $-80 / \mathrm{min}$

Temperature - $95.6 \mathrm{~F}$

Height $-163 \mathrm{Cm}$, Weight $-60 \mathrm{~kg}, \mathrm{BMI}-22.6$

Others (oedema, pallor, icterus, cyanosis) - absent

The general conditions are good. He had normal bowel habits with regular micturition. He is Vata kapha Prakruti.

\section{Local examination}

\section{Inspection}

- No oedema, No hyperpigmentation

- No joint deformity

- No congenital defects

\section{Palpation}

- Tenderness - Grade 2 (L3 - S1)

- Temperature of surrounding area - normal

- No oedema

\section{Range of movements}

- Flexion - painful

- Extension - painful

- Lateral bending - painful

Investigation: Blood routine - all the values were found normal (Hb, TC, DC, FBS, PPBS, ESR)

Diagnosis: This case is diagnosed as low back ache, from history taking and through examination.

\section{Ethical approval}

A written consent was taken from the patient.

Low back ache can be correlated to jangha asthigata vata in Ayurveda. For Vata disorders Basti is the primordial treatment. 
Anuvasana Basti with Ketakyadi taila is administered for continuous 9 days. The patient was advised for follow up after 18 days $\left(36^{\text {th }}\right.$ day of treatment)

\section{RESULT}

The clinical features like low back pain and stiffness relieved considerably after 9 days of treatment. Limitation in the movements of joint reduced. After the follow up, the patient was feeling better enough. Range of movements of Lumbo-sacral joint before and after treatment and after follow up is given in the table below. The measurements are taken using Goniometer.

Table 1: Range of movements of lumbo-sacral joint

\begin{tabular}{|c|c|c|c|}
\hline Range of movements & BT & AT & FU \\
\hline Flexion & $30^{0}$ & $40^{0}$ & $45^{0}$ \\
\hline Extension & $10^{0}$ & $16^{0}$ & $20^{0}$ \\
\hline Lateral bending & $5^{0}$ & $8^{0}$ & $12^{0}$ \\
\hline
\end{tabular}

Table 2: Day by day Lakshanas of Anuvasana Basti

\begin{tabular}{|c|c|c|c|c|c|c|c|c|c|}
\hline Samyak lakshanas & Day1 & $\mathbf{2}$ & $\mathbf{3}$ & $\mathbf{4}$ & $\mathbf{5}$ & $\mathbf{6}$ & $\mathbf{7}$ & $\mathbf{8}$ & $\mathbf{9}$ \\
\hline Sapureesha snehanivruti & $\mathrm{Y}$ & $\mathrm{Y}$ & $\mathrm{Y}$ & $\mathrm{Y}$ & $\mathrm{Y}$ & $\mathrm{Y}$ & $\mathrm{Y}$ & $\mathrm{Y}$ & $\mathrm{Y}$ \\
\hline Sanila snehanivruti & $\mathrm{Y}$ & $\mathrm{Y}$ & $\mathrm{Y}$ & $\mathrm{Y}$ & $\mathrm{Y}$ & $\mathrm{Y}$ & $\mathrm{Y}$ & $\mathrm{Y}$ & $\mathrm{Y}$ \\
\hline Swapnanuvriti & & & & $\mathrm{Y}$ & $\mathrm{Y}$ & $\mathrm{Y}$ & $\mathrm{Y}$ & $\mathrm{Y}$ & $\mathrm{Y}$ \\
\hline Laghuta & & & & & & $\mathrm{Y}$ & $\mathrm{Y}$ & $\mathrm{Y}$ \\
\hline Balam & & & & & & & $\mathrm{Y}$ & $\mathrm{Y}$ \\
\hline Srishtavega & & & $\mathrm{Y}$ & $\mathrm{Y}$ & $\mathrm{Y}$ & $\mathrm{Y}$ & $\mathrm{Y}$ & $\mathrm{Y}$ \\
\hline
\end{tabular}

\section{DISCUSSION}

This study was done to know the effectiveness of Anuvasana Basti with Ketakyadi taila in Low backache. In Ayurveda, low back ache can be correlated with Jangha asthigata vata. For this Basti, especially Anuvasana basti is prime line of treatment.

For the treatment purpose, Ketakyadi taila is prepared. Anuvasana basti was done for 9 days. Ketaki (Pandanus odoratissimus), Atibala (Abutilon indicum), Bala (Sida retusa), Tila taila and Tushodaka are the ingredients of this taila yoga ${ }^{6}$.

Most of the drugs are Madhura in Rasa and Vipaka and Vata Kapha hara in nature.

Madhura has Vata samana property. Taila is Agreya aushadha for vata vikaras. Bala and Atibala have anti-inflammatory and analgesic action. The Tushodaka being an Amla dravya prevents the Amatwa effect due to continuous administration of Sneha. So Ketakyadi taila is one of the best yoga for Anuvasana Basti. The taila is specially indicated in Asthi majjagata vata.

As a part of Poorvakarma, the patient underwent full body oil massage followed by hot water bath. Then Ushna, Laghu, Dravapraya ahara was given. Immediately after food intake, Anuvasana basti was administered. The retention time was less as compared with that of Matra basti.

The Vyadhi bala and Rogi bala of the patient were Pravara and suitable for doing Anuvasana basti. Anuvasana basti was done 9 days continuously. Samyak anuvasita lakshanas obtained. No Basti vyapat noted. The patient was asked to take rest and to follow Pathya in Ahara and Vihara. Remarkable improvement in pain, joint movements and stiffness noted throughout the procedure. Thus it can be concluded that Anuvasana basti with Ketakyadi taila has great effect in curing Low back ache.

\section{CONCLUSION}

Anuvasana basti with Ketakyadi taila is very effective in low back ache. Before administering Anuvasana basti, the physician has to assess the Amatwa, Agni and Koshtha of the patient.

\section{REFERENCES}

1. Vagbhata, Ashtanga Hridaya, Sutra Sthana (Sanskrit) Sarvanga Sundara of Arunadatta and Ayurveda Rasayana of Hemadri commentary, Bhisagacharya Harishastri Paradkar Vaidya, Varanasi: Chaukhamba Sanskrit series; 2011. p. 272. $19 / 6$

2. Low back ache. https://en.wikipedia.org/wiki/low back ache. Viewed on 10/1/2021 at $10 \mathrm{pm}$

3. Nicki R. Colledge, Brian R. Walker, Stuart H. Ralston. Davidson's principles and practice of medicine, Musculo skeletal diseases - Low back pain, $21^{\text {st }}$ edition, Elsevier publication; 2011. p. 1072.

4. Graham Douglas, Fiona Nicole, Colin Robertson, Macleod's clinical examination. The musculoskeletal system, $13^{\text {th }}$ edition, Elsevier publication; 2013. p. 333.

5. Agnivesha, Charaka Samhita Siddhi Sthana (Sanskrit) Ayurveda Dipika, Chakrapani Dutta commentary, Acharya Yadavaji Trikamaji, Varanasi: Chaukhambha Orientalia; 2013. p. 682. $1 / 31$

6. M. Narayanan Vaidhyar, Sahasrayogam (Malayalam) Taila yogas - Ketakyadi tailam: $1^{\text {st }}$ edition, Kannur, Ashoka Pharmaceuticals Kanuur-Kerala; 2001. p. 184.

\section{Cite this article as:}

Gopitha P. G. and Joshi George. A Case Study: Anuvasana Basti with Ketakyadi tailam in Low Backache. Int. J. Res. Ayurveda Pharm. 2021;12(3):1-2 http://dx.doi.org/10.7897/2277$\underline{4343.120364}$ 